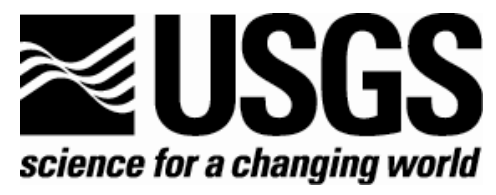

\title{
Ostracodes in Core BL00-1-D from Bear Lake, Utah and Idaho: Preliminary Analyses
}

By Jordon Bright and Darrell Kaufman

Open-File Report 2005-1226

U.S. Department of the Interior

U.S. Geological Survey 


\section{U.S. Department of the Interior \\ Gale A. Norton, Secretary}

\section{U.S. Geological Survey \\ Charles G. Groat, Director}

U.S. Geological Survey, Reston, Virginia 2005

For sale by U.S. Geological Survey, Information Services

Box 25286, Denver Federal Center

Denver, CO 80225

For more information about the USGS and its products:

Telephone: 1-888-ASK-USGS

World Wide Web: http://www.usgs.gov/

Any use of trade, product, or firm names in this publication is for descriptive purposes and does not imply endorsement by the U.S. Government.

Although this report is in the public domain, permission must be secured from the individual copyright owners to reproduce any copyrighted material contained within this report.

This report has not been reviewed for stratigraphic nomenclature.

Suggested citation:

Bright, J. and Kaufman, D., 2005, Ostacodes in Core BL00-1-D from Bear Lake, Utah and Idaho: Preliminary Analyses: U.S. Geological Survey Open-File Report 2005-1226, 5p.

Prepared by the U.S. Geological Survey in Denver, Colorado (http://climchange.cr.usgs.gov/) 


\section{Ostracodes in Core BLO0-1-D from Bear Lake, Utah and Idaho: Preliminary Analyses}

By Jordon Bright and Darrell Kaufman

\section{Introduction}

Thirty-six core catcher samples from GLAD800 core 00-1D taken at about $3 \mathrm{~m}$ intervals were analyzed for their ostracode assemblages. The goal was to assess the extent of preservation and the firstorder changes in ostracode fauna through the about 120-m-long core. Samples were collected aboard the GLAD800 rig and were provided by Brian Haskell, Limnological Research Center, University of Minnesota.

\section{Methods}

Samples were disaggregated in a weak sodium hexametaphosphate solution for several days and were washed over a $100 \mu \mathrm{m}$ sieve to retrieve the ostracodes. The recovered residue was air dried overnight. Whole adult ostracodes were counted and identified to species level. The ostracode fauna consisted of several new species of Candona, two new species of Limnocythere, Cytherissa lacustris, and one new genus. All the ostracode species, other than Cytherissa lacustris, are endemic to Bear Lake. Scanning electron microscope images of the endemic taxa are available in Bright and others (2005). Valves of individual Candona sp. 1 were collected from each sample for amino acid analysis. The remaining valves are archived at Northern Arizona University's Amino Acid Geochronology Laboratory.

\section{Results}

The major trends in the ostracode abundance and faunas are described below from top to bottom. Raw counts are included in the attached spreadsheets. Changes in the major taxa are shown on figure 1.

Core catcher (cc) samples 2 through 21, and 30 and 32, contained whole and fragmented valves. Core catcher samples 22-29, 31, and 33-36 contained only fragmented valves. The loss of whole valves in the deeper samples most likely is the result of sediment compaction. 


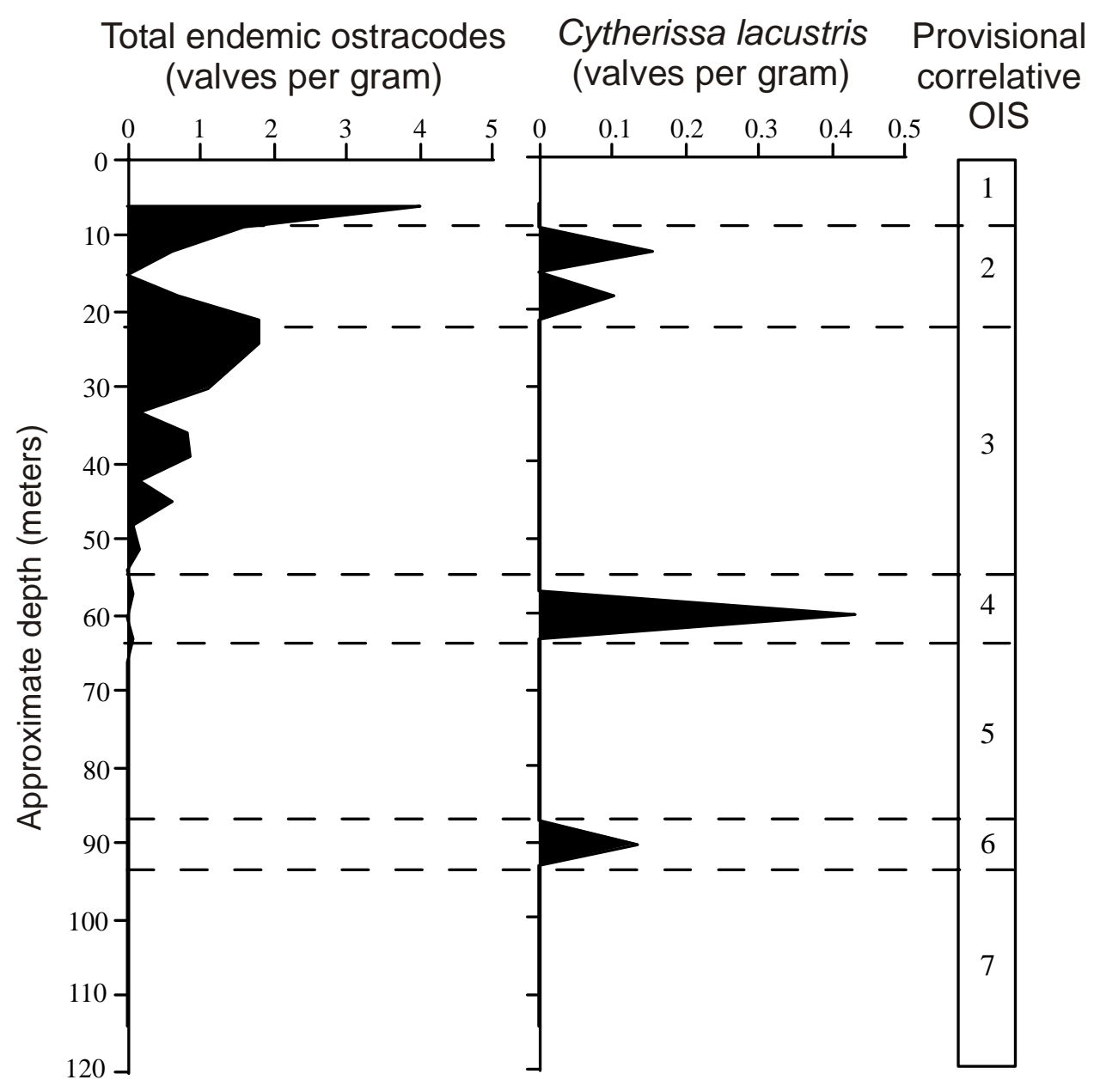

Figure. 1. Provisional correlation between ostracode changes in core catcher samples from GLAD800 core BL00-1D and the marine oxygen isotope stages (OIS), Note: Limnocythere sp. 1 juveniles and fragments found at 93, 96 and $102 \mathrm{~m}$. Cytherissa lacustris juveniles found at $~ 57,108$ and $111 \mathrm{~m}$.

Sample cc 2 had the highest number of valves per gram (vpg) of sediment (4.2 vpg), as well as the highest species diversity (7 species). All species in sample cc 2 are endemic to Bear Lake.

Samples cc 3-8 show a reduction in species diversity (1-5 species) and a reduction in the number of whole valves (1.8 vpg). Cytherissa lacustris appears in samples cc 4 and 6 indicating dilute water. All other ostracodes are typical endemic fauna, but primarily Candona sp. 1. Sample cc 5 was composed of red mud, similar to the sediment at the base of core 96-2 and throughout 96-3. No ostracodes were recovered from this sample.

Samples cc 10-21 contain only one or two species of ostracodes in low concentrations (0.1-1.1 vpg). Candona sp. 1 is present through all of these samples except cc 20 and is accompanied by Candona sp. 5 in cc 10 and cc 12-14. Juveniles of Cytherissa lacustris appear with Candona sp. 1 in cc 19, and adults of Cytherissa lacustris are the sole ostracode present in cc 20.

Samples cc 22-29 were devoid of whole ostracodes.

Sample cc 30 contains Cytherissa lacustris as the sole species, again indicating dilute or fresh water (Delorme, 1989). Sample cc 32 contains an isolated occurrence of Candona sp. 2 - the only ostracode present in that sample. Samples cc 33-35 did not contain whole ostracodes. Samples cc 36 and 
37 contained juveniles of the freshwater indicator Cytherissa lacustris. Fragments of Limnocythere sp. 1 were found in cc 31 and 34. Juveniles of that species were found in cc 32. These are the only occurrences of Limnocythere sp. 1 outside of Holocene samples and may indicate conditions similar to the Holocene. These occurrences of Limnocythere sp. 1 are bracketed by samples containing Cytherissa lacustris and indicate potentially rapid fluctuations between a slightly saline $(\sim 1,000 \mathrm{mg} / \mathrm{L})$ "Limnocythere-type" lake and a dilute $(<\sim 300 \mathrm{mg} / \mathrm{L}$ : Delorme, 1989) "Cytherissa lacustris-type" lake. On this basis, we suggest a provisional correlation with the marine oxygen isotope stratigraphy (fig. 1.).

\section{References}

Bright, J., Forester, R., and Kaufman, D.S., 2005, 0stracode Analysis for Cores BL96-1 and BL96-2 from Bear Lake, Utah and Idaho: U. S. Geological Survey Open-File Report 2005-1227, 13p.

Delorme, L.D., 1989, Methods in Quaternary Ecology 7: Freshwater Ostracodes: Geoscience Canada v. 16, p. 85-90. 